\title{
Pengetahuan Dan Dukungan Suami Dalam Penggunaan KB Suntik
}

\author{
Knowledge And Husband Support In The Use Of Injury KB \\ Nurmaliza $^{1}$, Wiwi Sartika ${ }^{2}$, Siti Qomariah ${ }^{3}$ \\ 1,2,3 Program Studi D III Kebidanan Universitas Abdurrab \\ ${ }^{1}$ Email: nurmaliza@univrab.ac.id
}

\begin{abstract}
ABSTRAK
Penggunaan alat kontrasepsi merupakan salah satu cara untuk mengendalikan ledakan penduduk. Diperkirakan pada tahun 2013 percepatan pertumbuhan penduduk di dunia mengalami peningkatan lebih tinggi. Pada tahun 2025 penduduk dunia akan naik menjadi 8,1 miliar, dan akan terus berkembang pada tahun 2050 menjadi 9,6 miliar. Penelitian ini bertujuan untuk melihat hubungan pengetahuan dan dukungan suami dalam penggunaaan KB Suntik di Klinik Pratama Afiyah. Metode penelitian ini dengan survey analitik menggunakan design cross sectional. Pelaksanaannya pada tanggal 01 sampai 31 Desember 2019 di Klinik Pratama Afiyah. Dengan populasi yaitu ibu aseptor KB yang berkunjung dikilinik dengan jumlah 57 responden. Tehnik pengambilan sampel dengan Accidental Sampling. Instrument penelitian yang digunakan adalah kuesioner. Prosedur pengolaan data dengan Editing, Coding, Processing, Cleaning. Analisis yang digunakan secara univariat, bivariate dan multivariate. Analisa Bivariat menggunakan uji chi-square dengan tingkat kepercayaan 95\%. Dari hasil penelitian didapatkan bahwa pengetahuan didapatkan nilai $\mathrm{p}$-value $=.002$, sedangkan dukungan suami $\mathrm{p}$-value $=.000$. Jadi dapat disimpulkan bahwa pengetahuan dan dukungan suami sangat mempengaruhi dalam penggunaan kontrasepsi KB.
\end{abstract}

Kata Kunci: Pengetahuan, Dukungan Suami, KB suntik..

\section{ABSTRACT}

The use of contraceptives is one way to control the population explosion. It is estimated that in 2013 the world population growth acceleration will experience a higher increase. In 2025 the world's population will increase to 8.1 billion, and will continue to grow in 2050 to become 9.6 billion. This study aimed to see the relationship between knowledge and support from husbands in the use of injection family planning at the Afiyah Pratama Clinic. This research method with analytic survey using cross sectional design. It will be held on December 1 to 312019 at the Afiyah Pratama Clinic. With the population, namely family planning acceptors who visited dikilinik with a total of 57 respondents. The sampling technique was using Accidental Sampling. The research instrument used was a questionnaire. Data processing procedures include Editing, Coding, Processing, Cleaning. The analysis used was univariate, bivariate and multivariate. Bivariate analysis using the chi-square test with a confidence level of $95 \%$. From the research results, it was found that the knowledge obtained p-value $=.002$, while husband's support was p-value $=.000$. So it can be concluded that the husband's knowledge and support greatly influence the use of contraceptives.

Keywords: Knowledge, Husband Support, KB injection

\section{PENDAHULUAN}

Diperkirakan pada tahun 2013 percepatan pertumbuhan penduduk di dunia mengalami peningkatan lebih tinggi. Pada tahun 2025 penduduk dunia akan naik menjadi 8,1 miliar, dan akan terus berkembang pada tahun 2050 menjadi 9,6 miliar.

Salah satu cara yang digunakan untuk menekan laju pertumbuhan penduduk adalah melalui pengendalian angka kelahiran. Pemerintah melalui Badan Kependudukan dan Keluarga 
Berenca na (BKKBN) telah menerapka $\mathrm{n}$ program KB yang dimulai sejak tahun 1970 (BKKBN, 2012).

Program KB BERTUJUAN memberikan kesempatan untuk mengatur jarak kelahiran atau mengurangi jumlah kelahiran dengan menggunakan metode kontrasepsi hormon atau kontrasepsi nonhormon. Ini bersifat sementara ataupun permanen, meskipun masing-masing jenis kontrasepsi memiliki tingkat efektifitas yang berbeda dan hampir sama (Gustikawati, 2014).

Angka pencapaian akseptor KB di Indonesia pada tahun 2011 dari 45.905.815 Pasangan Usia Subur (PUS) se banyak $34.872 .054(75,96 \%)$ telah menjadi akseptor $\mathrm{KB}$ aktif. Jumlah akseptor KB jangka panjang seperti IUD hanya se besar $11,28 \%, \mathrm{~KB}$ implant $8,82 \%$, MOW 3,49\%, dan jumlah akseptor KB terbanyak masih didominasi akseptor KB suntikyaitu se besar 46, $47 \%$.

Kontrasepsi suntik merupakan salah satu metode kontrasepsi yang banyak digunakan di Indonesia. Penggunaan kontrasepsi hormonal sebagai salah satu alat kontrasepsi meningkat drastis. Metode kontrasepsi yang memiliki efektifitas tinggi baik suntik 1 bulan maupun yang 3 bulan.
Pemilihan Kontrasepsi oleh wanita usia subur yang sesuai keinginan sangat penting, salah satu kontrasepsi yang banyak dipilih adalah KB suntikan baik 1 bulan mauun 3 bulan, karena suntik merupakan alat kontrasepsi yang praktis, aman, murah. Faktor yang mempengaruhi dalam menggunakan KB suntik, antara lain yaitu: Pengetahuan, Pendidikan, Umur, Media Informasi, Ketersediaan alat, , Petugas Kesehatan, Dukungan Suami. (Astuti, 2010).

Metode kontrasepsi hormon dapat dibagi menjadi 2 antara lain kombinasi (ada hormon progesteron dan estrogen sintetik) dan yang ada berisi progesteron saja. Kontrasepsi hormonal kombinasi terdapat pada pil dan suntik. Pada sebagian akseptor lebih memilih metode kontrasepsi suntik, karena alasan praktis yaitu sederhana dan tidak perlu takut lupa. Kontrasepsi suntik memiliki efektifitas yang tinggi bila penyuntikan dilakukan secara teratur dan sesuai jadwal yang telah ditentukan (Handayani, 2010)

Tujuan dari penelitian ini adalah untuk melihat pengetahuan dan dukungan suami dalam penggunaan $\mathrm{KB}$ suntik di Klinik Pratama Afiyah Tahun 2020. 


\section{METODE PENELITIAN}

Metode yang dipakai dalam penelitian ini adalah survey analitik dengan design cross sectional. Yang dilakukan pada tanggal 01 sampai 31 Desember 2019 di Klinik Pratama Afiyah Pekanbaru. Populasi seluruh ibu aseptor yang datang di klinik pratama afiyah Pekanbaru dengan jumlah 57 orang yang menggunakan KB suntik 3 bulan. Tehnik penggunakan data dengan menggunakan Accidental Sampling dimana sampel diambil secara kebetulan sebagai responden. Adapun Instrument yaitu kuesioner. Prosedur pengolaan data dengan Editing, Coding, Processing, Cleaning. Analisis data dengan univariat, bivariate dan multivariat. Analisa Bivariat dengan menggunakan uji chi-square dengan tingkat kepercayaan 95\% $(\alpha \leq 0,05)$ (Sugiyono, 2017).

\section{HASIL DAN PEMBAHSAN}

\section{A. Karakteristik Responden}

Dalam penelitian ini adalah seluruh ibu pengguna aseptor $\mathrm{KB}$ suntik yang datang di Klinik Pratama Afiyah Pekanbaru. Hasil analisis yang mempengaruhi aseptor $\mathrm{KB}$ suntik dapat dilihat pada karakteristik responden sebagai berikut:

Tabel 1 Distribusi Frekuensi Analisis

\begin{tabular}{lll}
\multicolumn{3}{c}{ Univariat Responden } \\
\hline Variabel & Frekuensi & $\%$ \\
\hline Pengetahuan & & \\
Baik & 40 & 70.2 \\
Kurang & 17 & 29,8 \\
Dukungan Suami & Frekuensi & $\%$ \\
Mendukung & 31 & 54.4 \\
Tidak Mendukung & 26 & 45,6 \\
\hline
\end{tabular}

Berdasarkan tabel diatas diketahui bahwa Mayoritas Responden berpengetahuan baik sebanyak 40 orang dengan $70,2 \%$. Mayoritas dukungan suami yang mendukung 31 orang dengan $54,4 \%$.

\section{B. Analisis Bivariat}

Tabel 2 Analisis pengetahuan dan dukungan suami dalam penggunaan Kontrasepsi KB Suntik

\begin{tabular}{|c|c|c|c|c|c|c|c|c|}
\hline \multirow{3}{*}{ Variabel Independen } & \multicolumn{4}{|c|}{ KB Suntik } & \multirow{3}{*}{$\begin{array}{c}\mathbf{J M L} \\
\mathbf{N}\end{array}$} & \multirow{3}{*}{$\begin{array}{l}\% \\
\%\end{array}$} & \multirow[t]{3}{*}{$P$} & \multirow[t]{3}{*}{ OR } \\
\hline & \multicolumn{2}{|c|}{ Menggunakan } & \multirow{2}{*}{$\underset{\mathbf{N}}{\text { Tidak }}$} & \multirow{2}{*}{$\begin{array}{c}\text { Menggunakan } \\
\%\end{array}$} & & & & \\
\hline & $\mathbf{N}$ & $\%$ & & & & & & \\
\hline Pengetahuan & & & & & & & & \\
\hline Baik & 31 & $77.5 \%$ & 9 & $22.5 \%$ & 40 & 100 & .002 & $1.8-21.8$ \\
\hline Kurang & 6 & $35,3 \%$ & 11 & $64.7 \%$ & 17 & 100 & & \\
\hline Dukungan Suami & & & & & & & & \\
\hline Mendukung & 28 & $90,3 \%$ & 3 & $9,7 \%$ & 31 & 100 & .000 & $4.18-74.32$ \\
\hline Tidak & 9 & 34,6 & 17 & 65,4 & 26 & 100 & & \\
\hline
\end{tabular}




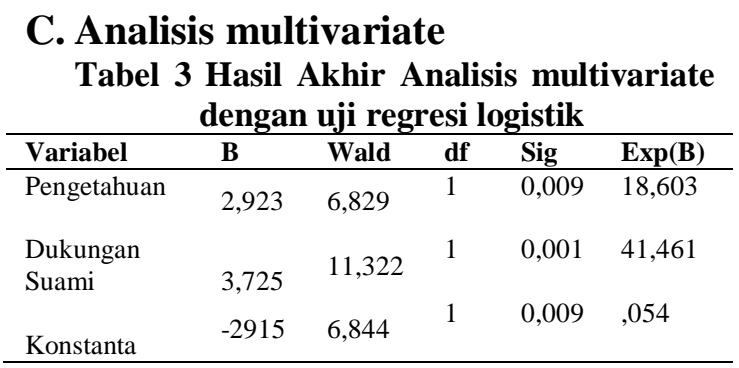

Pada table diatas variable yang mempengaruhi penggunaan $\mathrm{KB}$ suntik adalah dukungan suami dengan $\mathrm{p}=0,001$ sebanyak 41,4 kali mendapatkan dukungan dari suami dibandingkan dengan yang tidak mendapatkan dukungan dari suami. Sedangkan ibu yang berpengetahuan baik sebanyak 18,6 kali dibandingkan dengan ibu yang berpengetahuan kurang dalam penggunaan $\mathrm{KB}$ suntik dengan pvalue $=0,009$.

\section{Pengetahuan}

Berdasarkan hasil $\mathrm{P}$ Value Berdasarkan hasil $($ pvalue $=.002<0,05)$ dapat dinyatakan Hasil analisis bivariat dengan uji chi square didapat nilai $p=$ 0,002 yang artinya ada hubungan pengetahuan dengan penggunaan kontrasepsi KB suntik.

Perilaku seseorang didasari oleh pengetahuan, kesadaran dan sikap positif. Sehingga mempengaruhi perilaku tersebut terhadap wanita usia subur dalam menggunakan alat kontrasepsi KB suntik.. Hasil penelitian menunjukkan sebagian besar responden tingkat pengetahuannya tinggi karena sebagian besar responden memahami benar tentang jenis, manfaat, dan cara pemakaian alat kontrasepsi (Bernadus et all, 2013)

\section{Dukungan Suami}

Hasil analisis bivariat dengan uji chi square diperoleh nilai p.value $=.000$ yang artinya ada hubungan Dukungan Suami dengan penggunaan $\mathrm{KB}$ suntik.

Dukungan membuat keluarga mampu melaksanakan fungsinya, karena anggota keluarga memang seharusnya saling memberikan dukungan dan saling memperhatikan keadaan dan kebutuhan kesehatan istri. Dukungan suami terdiri dari 4 bentuk, yaitu dukungan informasional, penilaian, instrumental, dan emosional. Kontrasepsi tidak dapat dipakai istri tanpa adanya kerjasama suami dan saling percaya. Idealnya pasangan suami istri harus memilih metode kontrasepsi yang terbaik, saling bekerjasama dalam pemakaian, membayar biaya pengeluaran untuk kontrasepsi, dan memperhatikan tanda bahaya pemakaian (Hartanto, 2010). 


\section{SIMPULAN DAN SARAN}

Berdasarkan penelitian ini dapat di simpulkan bahwa ada hubungan yang signifikan antara pengetahuan dan dukungan suami terhadap penggunaan KB suntik, dimana dari 57 responden terdapat 40 responden berpengetahuan daik dan 31 responden mendapatkan dukungan dari suami. Harapan penulis hasil dari penelitian ini dapat dijadikan wawasan tambahan bagi responden dan menjadi tambahan rujukan bagi tenaga kesehatan serta pembaca.

\section{DAFTAR PUSTAKA}

Astuti, DY, 2010. Kontrasepsi Suntik. Diakses dari http://www.ktiskripsi.com/2010/ 05/kti-kb-suntik.html.pada tanggal 12 Maret 2011.

BKKBN. 2012. AlatBantu Pengambilan Keputusan Ber-KB Edisi 8. Jakarta: BKKBN

Bernadus JD, Madianung A, Masi G. 2013. Faktor-Faktor yang Berhubungan dengan Pemilihan Alat Kontrasepsi Dalam Rahim (AKDR) Bagi Akseptor KB di Puskesmas Jailolo. Jurnal eNERS (eNS), Volume 1, Nomor 1, Maret 2013

Gustikawati, D.A. 2014, Faktor Pendukung dan Penghambat Istri PUS dalam Penggunaan Alat Kontrasepsi Implant di Puskesmas 1 Denpasar Utara. Publikas Penelitian. Denpasar: Jurusan Kesehatan Masyarakat Universitas Udaya.

Hartanto, H. 2010. KB dan Kontrasepsi. Jakarta: Pustaka Sinar Harapan. 